\title{
HUBUNGAN ANTARA KEPEMILIKAN SIM C DAN KEIKUTSERTAAN DALAM TES PEMBUATAN SIM DENGAN PENGETAHUAN BERKENDARA DAN KECELAKAAN LALU LINTAS DI KABUPATEN SIDOARJO
}

\author{
Fadilah Andy Nastiti \\ Fakultas Kesehatan Masyarakat, Universitas Airlangga \\ Surabaya, Jawa Timur, Indonesia \\ Alamat Korespondensi: \\ Fadilah Andy Nastiti \\ Email: dilanastiti@yahoo.co.id
}

\begin{abstract}
Traffic accidents are one of the biggest causes of death in the world. WHO states that $90 \%$ of deaths that caused by traffic accident in the world occur in low and middle income countries. Indonesia is ranked first with the highest percentage of deaths that caused by traffic accident in Asia. Most traffic accidents involve motorcyclist with an average age of 15-29 years old. The purpose of this study is to determine the correlation between ownership of driving license and participation in driving license tests with driving knowledge and traffic accidents in high school students of Xi grade in Kabupaten Sidoarjo in 2017. This research was an observational analytic with cross sectional study design. The population of this study was all senior high school students of XI grade in Kabupaten Sidoarjo in 2017. The number of respondents was 204 students that drawn from the population by using two stage cluster random sampling method. Results of analysis using chi square and fisher's exact test $(\alpha=5 \%)$ indicate that the ownership of driving license ( $p=0.259 ; R R 1.533)$ and participation in driving license test $(p=1.00 ; R R$ $0.586)$ did not have correlation with traffic accidents in high school students of XI grade in Kabupaten Sidoarjo in 2017 and the ownership of driving license ( $p=1.00 ; R R$ 1.008) and participation in driving license test ( $p=1,00 ; R R$ 0.983) did not have correlation too with driving knowledge in high school students of XI grades in Kabupaten Sidoarjo in 2017.
\end{abstract}

Keywords: traffic accident, high school students, driving knowledge, driving license

\begin{abstract}
ABSTRAK
Kecelakaan lalu lintas merupakan salah satu penyebab kematian terbesar di dunia. WHO menyatakan 90\% kematian karena kecelakaan lalu lintas di dunia terjadi di negara berpenghasilan rendah dan menengah. Jika dilihat dari persentase statistik jumlah populasi, Indonesia berada di peringkat pertama dengan angka kematian akibat kecelakaan tertinggi di Asia. Kecelakaan lalu lintas paling banyak melibatkan pengendara sepeda motor dengan rata-rata usia 15-29 tahun dimana usia tersebut merupakan usia produktif. Penelitian ini bertujuan untuk mengetahui hubungan antara kepemilikan SIM C dan keikutsertaan dalam tes pembuatan SIM dengan pengetahuan berkendara dan kecelakaan lalu lintas pada siswa SMA kelas XI di Kabupaten Sidoarjo tahun 2017. Jenis penelitian ini merupakan penelitian observasional analitik dengan desain cross sectional. Populasi penelitian adalah seluruh siswa SMA kelas XI di Kabupaten Sidoarjo pada tahun 2017. Jumlah responden dalam penelitian ini sebanyak 204 siswa yang ditarik dari populasi dengan metode two stage cluster random sampling. Hasil analisis dengan menggunakan uji chi-square dan fisher's exact $(\alpha=5 \%)$ menunjukkan bahwa kepemilikan SIM C $(\mathrm{p}=0,259 ; \mathrm{RR} 1,533)$ dan keikutsertaan dalam tes $\operatorname{SIM}(\mathrm{p}=1,00 ; \mathrm{RR} 0,586)$ tidak mempunyai hubungan dengan kecelakaan lalu lintas pada siswa SMA kelas XI di Kabupaten Sidoarjo serta kepemilikan SIM C $(\mathrm{p}=1,00 ; \mathrm{RR} 1,008)$ dan keikutsertaan dalam tes $\operatorname{SIM}(\mathrm{p}=1,00 ; \mathrm{RR} 0,983)$ tidak mempunyai hubungan pula dengan pengetahuan berkendara pada siswa SMA kelas XI di Kabupaten Sidoarjo.
\end{abstract}

Kata kunci: kecelakaan lalu lintas, siswa SMA, pengetahuan berkendara, SIM 


\section{PENDAHULUAN}

Salah satu penyebab kematian di dunia adalah kecelakaan lalu lintas. Pada tahun 2015, World Health Organization (WHO) memublikasikan sebuah laporan yakni The Global Report on Road Safety yang didalamnya menyatakan sekitar 1,25 juta orang di dunia meninggal dunia pada tahun 2013 akibat kecelakaan lalu lintas jalan. Laporan ini juga menyatakan bahwa 90\% kematian akibat kecelakaan lalu lintas di dunia terjadi di negara berpenghasilan rendah dan menengah yang juga merupakan negara penyumbang 54\% kendaraan di dunia. Menurut The Global Report on Road Safety 2015, kecelakaan lalu lintas merupakan penyebab utama kematian di kalangan anak muda dunia berusia 15-29 tahun.

Indonesia merupakan negara berkembang dan berpenghasilan menengah dengan populasi penduduk terbanyak ke empat di dunia. Menurut The Global Report on Road Safety tahun 2015, Indonesia menduduki peringkat ketiga se-Asia untuk jumlah kematian terbanyak akibat kecelakaan lalu lintas di bawah Tiongkok dan India dengan total 38.279 kematian. Faktanya, menurut The Global Report on Road Safety tahun 2015, jika dilihat dari persentase statistik jumlah populasi, Indonesia menduduki peringkat pertama dengan angka kematian akibat kecelakaan lalu lintas sebesar $0,015 \%$ dari jumlah populasi. Populasi penduduk yang banyak menjadikan Indonesia sebagai pengguna kendaraan bermotor yang tinggi pula, terutama sepeda motor. Menurut Ketua Asosiasi Industri Sepeda Motor Indonesia (AISI), perbandingan antara jumlah masyarakat Indonesia dan jumlah sepeda motor sama dengan satu banding tiga. Sepeda motor dipilih masyarakat karena harganya yang relatif terjangkau daripada moda transportasi lain sehingga kepadatan di jalan didominasi oleh sepeda motor. Tingginya jumlah sepeda motor di Indonesia menyebabkan tingginya kecelakaan lalu lintas yang melibatkan sepeda motor.
Menurut data Publikasi Perhubungan Darat dalam Angka pada 2014, jumlah kecelakaan berdasarkan jenis kendaraan yang terlibat kecelakaan lalu lintas didominasi oleh sepeda motor yakni sebesar 108.883 kejadian disusul dengan mobil penumpang 18.147 kejadian, mobil beban 19.242 kejadian, bus 4.808 kejadian, dan kendaraan khusus 1.050 kejadian. Dari data tersebut dapat dilihat bahwa moda transportasi sepeda motor masih merupakan penyumbang kecelakaan lalu lintas terbesar di jalan raya. Tingginya jumlah sepeda motor di Indonesia tidak diimbangi dengan meningkatnya kesadaran berkendara yang baik dan aman sehingga pengguna sepeda motor masih berisiko mengalami kecelakaan lalu lintas. Faktor manusia merupakan faktor dominan penyebab kecelakaan lalu lintas. Menurut data kepolisian nasional, penyebab utama kecelakaan adalah human error. Sebagian besar kecelakaan terjadi karena diawali dengan pelanggaran, pelanggaran rambu lalu lintas misalnya. Pelanggaran rambu lalu lintas dapat terjadi karena memang disengaja, ketidaktahuan atau tidak adanya kesadaran terhadap arti aturan yang berlaku.

Menurut Dirlantas Polda Jatim pada tahun 2015, Provinsi Jawa Timur menduduki peringkat teratas untuk tingginya kejadian kecelakaan lalu lintas di Indonesia dan salah satu kabupaten dengan jumlah kejadian kecelakaan terbesar adalah Kabupaten Sidoarjo.

Tabel 1. 5 Kabupaten di Jawa Timur dengan Kejadian Kecelakaan Tertinggi tahun 2013

\begin{tabular}{lc}
\hline \multicolumn{1}{c}{ Kota/Kabupaten } & $\begin{array}{c}\text { Jumlah Kejadian } \\
\text { Kecelakaan }\end{array}$ \\
\hline Kab. Kediri & 1045 \\
Kab. Sidoarjo & 1024 \\
Kab. Jombang & 927 \\
Kab.Tuban & 858 \\
Kota Surabaya & 837 \\
\hline
\end{tabular}


Menurut data Badan Pusat Statistik Provinsi Jawa Timur dalam Publikasi Jawa Timur dalam Angka tahun 2015 pada tabel 1 di atas, Kabupaten Sidoarjo berada di peringkat kedua untuk kabupaten dengan jumlah kejadian kecelakaan lalu lintas terbanyak di Provinsi Jawa Timur di bawah Kabupaten Kediri dengan jumlah kecelakaan lalu lintas pada tahun 2013 sebesar 1024 kejadian. Dari data yang diberikan oleh Polres Sidoarjo, sebagian besar pelaku dan korban kecelakaan berada di rentang umur produktif, yakni 16-30 tahun dengan pelaku kecelakaan berjumlah 473 orang dan korban kecelakaan berjumlah 689 orang. Umur produktif merupakan rentang umur seseorang dianggap dapat berproduksi atau menghasilkan sesuatu sehingga umur ini merupakan umur dimana seseorang berada di puncak aktivitasnya dan sedang aktif sebagai sumber mata pencaharian untuk meningkatkan kesejahteraan keluarga.

Undang-Undang No. 22 Tahun 2009 tentang lalu lintas dan angkutan jalan pasal 77 menyatakan bahwa setiap orang yang mengemudikan kendaraan bermotor di jalan wajib memiliki Surat Ijin Mengemudi (SIM) sesuai dengan jenis kendaraan yang dikemudikan. Hal ini menyatakan bahwa setiap orang yang berkendara wajib memiliki Surat Ijin Mengemudi (SIM), namun pada penelitian yang dilakukan oleh Kordelia, dkk (2014) yang dilakukan di beberapa wilayah di Sumatra Barat menunjukkan bahwa 11\% responden pengguna kendaraan di Padang, $34 \%$ responden pengguna kendaraan di Payakumbuh dan $50 \%$ responden pengguna kendaraan di Payakumbuh belum memiliki SIM C. Menurut data dari Polres Sidoarjo dari 1404 kejadian kecelakaan di Kabupaten Sidoarjo pada tahun 2016, sebanyak 147 pelaku kecelakaan masih belum memiliki Surat Ijin Mengemudi (SIM). Seperti yang telah diketahui bahwa untuk mendapatkan SIM diharuskan memenuhi beberapa persyaratan, yaitu usia, administratif, kesehatan dan lulus ujian. Ada persyaratan lulus ujian yang harus dilewati oleh para pengendara yang ingin mendapatkan SIM yang meliputi ujian teori, ujian praktik, dan/ atau ujian keterampilan melalui simulator. Ujian ini diharapkan mampu menilai pengetahuan dan keterampilan berkendara pengendara.

Tujuan penelitian ini adalah untuk mengetahui hubungan antara kepemilikan SIM C dan keikutsertaan dalam tes pembuatan SIM dengan pengetahuan berkendara dan kejadian kecelakaan lalu lintas di Kabupaten Sidoarjo pada tahun 2017.

\section{METODE PENELITIAN}

Penelitian ini merupakan penelitian observasional dimana peneliti hanya melakukan pengamatan pada subjek penelitian (responden) tanpa memberikan perlakuan. Tipe penelitian merupakan penelitian analitik yang bertujuan untuk menganalisis risiko kecelakaan lalu lintas berdasarkan kepemilikan SIM dan pengetahuan berkendara.

Rancang bangun penelitian yang digunakan adalah cross sectional karena penelitian ini bertujuan mempelajari korelasi antara faktor risiko yakni kepemilikan SIM dan pengetahuan berkendara dengan efek yakni kecelakaan lalu lintas dengan cara observasi dan pengumpulan data pada suatu saat/waktu yang sama pada subjek penelitian.

Penelitian dilakukan di SMA di wilayah Kabupaten Sidoarjo. Populasi dalam penelitian ini merupakan seluruh siswa kelas XI dari SMA yang berada di Wilayah Kabupaten Sidoarjo yang memenuhi kriteria inklusi. Terdapat dua kriteria inklusi populasi penelitian yakni merupakan pengendara sepeda motor aktif baik di lingkungan sekolah dan/atau di lingkungan rumah serta telah berumur 17 tahun ketika penelitian dilakukan.

Sampel penelitian ditarik secara acak dari populasi inklusi dengan menggunakan two stage cluster random sampling. Penggunaan teknik klaster dilakukan karena 
populasi terdiri dari kelompok-kelompok atau klaster. Tahap pertama dalam teknik ini yakni menentukan sampel daerah dengan menggunakan list cluster berupa daftar SMA di Kabupaten Sidoarjo yang berikutnya dilakukan pemilihan sampel secara acak dengan fraksi sebesar $10 \%$. Tahap berikutnya yakni menentukan orangorang yang ada pada daerah itu dengan menggunakan jumlah siswa kelas XI yang memenuhi kriteria inklusi pada tiap sekolah terpilih yang berikutnya dilakukan pemilihan secara acak dengan fraksi sebesar $10 \%$. Total sekolah yang terpilih sebagai sampel klaster sebanyak tujuh sekolah dan total siswa yang menjadi responden dalam penelitian ini sebanyak 204 responden.

Variabel dalam penelitian ini terdiri dari variabel terikat yakni kejadian kecelakaan lalu lintas, serta variabel bebas yakni jenis kelamin, kepemilikan SIM C, keikutsertaan dalam tes pembuatan SIM dan pengetahuan berkendara responden yang terbagi menjadi pengetahuan akan rambu lalu lintas, pengetahuan marka jalan, dan pengetahuan akan peraturan lalu lintas. Pengumpulan data dimulai dari bulan Mei hingga Juli 2017. Pengumpulan data didapat dari hasil jawaban kuesioner yang diisi mandiri oleh responden. Penentuan responden yang merupakan pengendara aktif sepeda motor dan berumur minimal 17 tahun dilakukan dengan cara wawancara langsung dengan responden.

Statistik deskriptif digunakan untuk menjelaskan distribusi karakteristik responden yang terdiri dari jenis kelamin, status kecelakaan lalu lintas enam bulan terakhir terhitung ketika penelitian dilakukan, kepemilikan SIM C, keikutsertaan dalam tes pembuatan SIM dan pengetahuan berkendara. Sementara, analisis data dilakukan untuk melihat hubungan antaran kepemilikan SIM $\mathrm{C}$ dan keikutsertaan dalam tes pembuatan SIM dengan pengetahuan berkendara dan kejadian kecelakaan lalu lintas pada pelajar SMA kelas XI di Kabupaten Sidoarjo tahun 2017 yang terdiri dari uji chi square dan
Tabel 2. Distribusi Karakteristik Responden berdasarkan Jenis Kelamin

\begin{tabular}{lcc}
\hline Jenis Kelamin & Jumlah & Persentase (\%) \\
\hline Laki-laki & 97 & 47,5 \\
Perempuan & 107 & 52,5 \\
\hline Jumlah & 204 & 100 \\
\hline
\end{tabular}

fisher exact. Uji fisher exact digunakan ketika salah satu syarat uji chi square tidak terpenuhi, yakni apabila lebih dari 20\% jumlah sel atau kategori yang ada memiliki frekuensi harapan kurang dari 5 dan apabila ada sel dengan nilai frekuensi kenyataan atau actual count sebesar 0 (nol). Hubungan antar variabel dapat diketahui dengan membandingkan $p$ value dengan $\alpha=0,05$.

\section{HASIL}

Tabel 2 menunjukkan bahwa karakteristik responden menurut jenis kelamin sebagian besar responden merupakan siswa perempuan, meskipun hampir tidak ada beda antara persentase laki-laki (47,5\%) dan perempuan (52,5\%). Sebagian besar responden berumur 17 tahun dan hanya tiga responden laki-laki dan tiga responden perempuan yang telah memasuki usia 18 tahun.

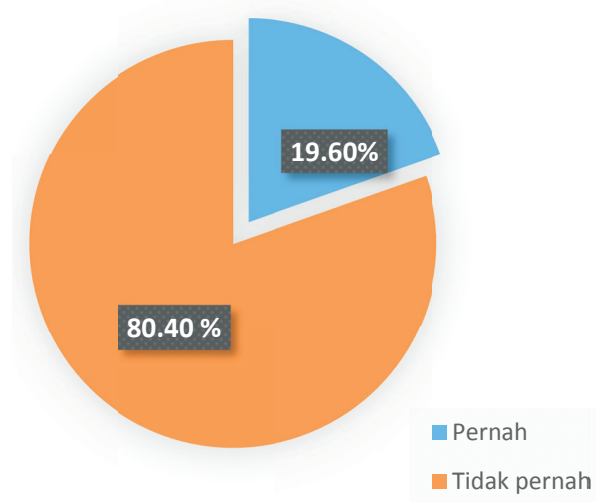

Gambar 1. Distribusi Karakteristik Responden berdasarkan Riwayat Kecelakaan Lalu Lintas

Gambar 1 menunjukkan bahwa hanya sebagian kecil responden $(19,6 \%)$ yang 
pernah mengalami kecelakaan selama enam bulan terakhir ketika penelitian dilakukan. Para responden yang pernah mengalami kecelakaan mengaku bahwa kejadian kecelakaan paling banyak terjadi ketika tidak dalam perjalanan berangkat maupun pulang sekolah.

Tabel 3. Distribusi Karakteristik Responden berdasarkan Kepemilikan SIM C

\begin{tabular}{lcc}
\hline $\begin{array}{c}\text { Kepemilikan } \\
\text { SIM C }\end{array}$ & Jumlah & $\begin{array}{c}\text { Persentase } \\
\text { (\%) }\end{array}$ \\
\hline Punya & 69 & 33,8 \\
Tidak punya & 135 & 66,2 \\
\hline Jumlah & 204 & 100 \\
\hline
\end{tabular}

Tabel 3 menunjukkan bahwa sebagian besar responden masih belum memiliki SIM $\mathrm{C}(66,2 \%)$ dan dari 69 responden yang telah memiliki SIM C sebagian besar merupakan siswa laki-laki $(69,6 \%)$.

Tabel 4. Distribusi Karakteristik Responden berdasarkan Keikutsertaan dalam Tes SIM C

\begin{tabular}{lcc}
\hline $\begin{array}{c}\text { Keikusertaan } \\
\text { dalam Tes SIM C }\end{array}$ & Jumlah & $\begin{array}{c}\text { Persentase } \\
\mathbf{( \% )}\end{array}$ \\
\hline Mengikuti tes & 58 & 84,1 \\
Tidak mengikuti tes & 11 & 15,9 \\
\hline Jumlah & 69 & 100 \\
\hline
\end{tabular}

Tabel 4 menunjukkan sebagian besar responden yang memiliki SIM C mengikuti tes dalam pembuatan SIM C $(84,1 \%)$ dan dari 58 responden yang mengikuti tes pembuatan SIM, beberapa responden $(15,5 \%)$ hanya mengikuti tes tulis saja tanpa mengikuti tes praktik.

Tabel 5 menunjukkan bahwa sebagian besar responden memiliki tingkat pengetahuan berkendara yang baik (98\%). Tingkat pengetahuan berkendara para responden ditanyakan dengan kuesioner yang berisi pertanyaan mengenai pengetahuan rambu lalu lintas, marka jalan, dan peraturan umum lalu lintas. Kategori pengetahuan baik
Tabel 5. Distribusi Karakteristik Responden berdasarkan Tingkat Pengetahuan Berkendara

\begin{tabular}{lcc}
\hline $\begin{array}{c}\text { Tingkat Pengetahuan } \\
\text { Berkendara }\end{array}$ & Jumlah & $\begin{array}{c}\text { Persentase } \\
\text { (\%) }\end{array}$ \\
\hline Baik & 200 & 98 \\
Kurang & 4 & 2 \\
\hline Jumlah & 204 & 100 \\
\hline
\end{tabular}

jika para responden berhasil menjawab $\geq 55 \%$ jawaban yang benar. Hasil analisis hubungan antara jenis kelamin, kepemilikan SIM C, dan keikutsertaan dalam tes pembuatan SIM dengan kecelakaan lalu lintas dan pengetahuan berkendara dapat dilihat dalam tabel 6 .

Tabulasi silang antara jenis kelamin dengan kejadian kecelakaan lalu lintas menunjukkan bahwa lebih dari setengah responden merupakan perempuan namun dari data didapatkan persentase kecelakaan lebih besar pada laki-laki meskipun jumlah status kecelakaan antara laki-laki dan perempuan sama yakni masing-masing 20 orang. Sementara tabulasi silang antara jenis kelamin dengan pengetahuan berkendara menunjukkan bahwa antara laki-laki dan perempuan memiliki persentase yang hampir sama besar untuk pengetahuan berkendara yang baik namun pada jenis kelamin perempuan persentase tingkat pengetahuan berkendara kategori kurang masih lebih tinggi. Uji chi square dengan tabel kontingensi 2 x 2 digunakan untuk melihat hubungan antara jenis kelamin dengan kejadian kecelakaan lalu lintas menghasilkan $p$ value sebesar 0,865 dimana nilai tersebut lebih besar dari $0,05(\alpha)$ yang artinya tidak ada hubungan antara jenis kelamin dengan kejadian kecelakaan lalu lintas pada pelajar SMA kelas XI di Kabupaten Sidoarjo. Sementara uji fisher's exact untuk melihat hubungan jenis kelamin dengan pengetahuan berkendara menghasilkan $p$ value 0,623 dimana nilai tersebut lebih besar dari $0,05(\alpha)$ yang artinya tidak ada hubungan antara jenis kelamin dengan pengetahuan berkendara 
Tabel 6. Analisis Hubungan Jenis Kelamin, Kepemilikan SIM C dan Keikutsertaan dalam Tes SIM dengan Kecelakaan Lalu Lintas dan Pengetahuan Berkendara

\begin{tabular}{|c|c|c|c|c|c|}
\hline \multirow{2}{*}{ Variabel } & \multicolumn{2}{|c|}{ Status Kecelakaan } & \multirow{2}{*}{$P$ value } & \multirow{2}{*}{$\mathbf{R R}$} & \multirow{2}{*}{ CI 95\% } \\
\hline & Pernah & Tidak pernah & & & \\
\hline \multicolumn{6}{|l|}{ Jenis Kelamin } \\
\hline Laki-laki & $20(20,6 \%)$ & $77(79,4 \%)$ & \multirow{2}{*}{0,865} & \multirow{2}{*}{1,103} & \multirow{2}{*}{$0,633-1,923$} \\
\hline Perempuan & $20(18,7 \%)$ & $87(81,3 \%)$ & & & \\
\hline \multicolumn{6}{|l|}{ Kepemilikan SIM C } \\
\hline Tidak punya & $30(22,2 \%)$ & $105(77,8 \%)$ & \multirow{2}{*}{0,259} & \multirow{2}{*}{1,533} & \multirow{2}{*}{$0,797-2,950$} \\
\hline Punya & $10(14,5 \%)$ & $59(85,5 \%)$ & & & \\
\hline \multicolumn{6}{|c|}{ Keikutsertaan dalam Tes SIM } \\
\hline Tidak mengikuti & $1(9,1 \%)$ & $10(90,9 \%)$ & \multirow{2}{*}{1,00} & \multirow{2}{*}{0,586} & \multirow{2}{*}{$0,082-4,171$} \\
\hline Mengikuti & $9(15,5 \%)$ & $49(84,5 \%)$ & & & \\
\hline \multirow{2}{*}{ Variabel } & \multicolumn{2}{|c|}{ Pengetahuan Berkendara } & \multirow{2}{*}{ P value } & \multirow{2}{*}{$\mathbf{R R}$} & \multirow{2}{*}{ CI 95\% } \\
\hline & Baik & Kurang & & & \\
\hline \multicolumn{6}{|l|}{ Jenis Kelamin } \\
\hline Laki-laki & $96(99 \%)$ & $1(1 \%)$ & \multirow{2}{*}{0,623} & \multirow{2}{*}{1,018} & \multirow{2}{*}{$0,980-1,058$} \\
\hline Perempuan & $104(97,2 \%)$ & $3(2,8 \%)$ & & & \\
\hline \multicolumn{6}{|l|}{ Kepemilikan SIM C } \\
\hline Punya & $68(98,6 \%)$ & $1(1,4 \%)$ & \multirow{2}{*}{1,00} & \multirow{2}{*}{1,008} & \multirow{2}{*}{$0,970-1,047$} \\
\hline Tidak punya & $132(98 \%)$ & $3(2,2 \%)$ & & & \\
\hline \multicolumn{6}{|c|}{ Keikutsertaan dalam Tes SIM } \\
\hline Mengikuti & $57(98,3 \%)$ & $1(1,7 \%)$ & \multirow{2}{*}{1,00} & \multirow{2}{*}{0,983} & \multirow{2}{*}{$0,950-1,017$} \\
\hline Tidak mengikuti & $11(100 \%)$ & 0 & & & \\
\hline
\end{tabular}

pada siswa SMA kelas XI di Kabupaten Sidoarjo.

Nilai Risk Ratio pada variabel jenis kelamin dengan kejadian kecelakaan lalu lintas adalah 1,103 yang memiliki arti siswa laki-laki berisiko mengalami kecelakaan lalu lintas 1,103 kali lebih besar daripada siswa perempuan. Nilai 95\% Confidence Interval dari Risk Ratio $(0,633-1,923)$ menunjukkan bahwa risiko tersebut tidak bermakna. Sementara nilai Risk Ratio pada variabel jenis kelamin dengan pengetahuan berkendara adalah 1,018 yang memiliki arti siswa lakilaki berisiko memiliki pengetahuan yang baik 1,018 kali lebih besar daripada siswa perempuan. Nilai 95\% Confidence Interval pada Risk Ratio $(0,980-1,058)$ menunjukkan bahwa risiko tersebut juga tidak bermakna.

Tabulasi silang antara kepemilikan SIM C dengan kejadian kecelakaan lalu lintas menunjukkan bahwa sebagian besar responden masih banyak yang belum memiliki SIM C dan persentase kecelakaan terbesar juga pada yang belum memiliki SIM C. Sementara tabulasi silang antara kepemilikan SIM C dan pengetahuan berkendara menunjukkan bahwa baik yang memiliki SIM C maupun tidak, memiliki persentase hampir sama besar pada pengetahuan berkendara kategori baik namun pada responden yang tidak memiliki SIM C memiliki persentase lebih besar pada pengetahuan berkendara kategori kurang daripada yang telah memiliki SIM C. Uji chi-square digunakan untuk melihat hubungan antara kepemilikan SIM C dengan kejadian kecelakaan lalu lintas menghasilkan $p$ value sebesar 0,259 dimana nilai tersebut lebih besar dari $0,05(\alpha)$ yang artinya tidak ada hubungan antara kepemilikan SIM C 
dengan kecelakaan lalu lintas pada siswa SMA kelas XI di Kabupaten Sidoarjo. Sementara uji fisher's exact untuk melihat hubungan antara kepemilikan SIM C dengan pengetahuan berkendara menghasilkan $p$ value sebesar 1,00 dimana nilai tersebut lebih besar dari $0,05(\alpha)$ yang artinya tidak ada hubungan antara kepemilikan SIM C dengan pengetahuan berkendara pada siswa SMA kelas XI di Kabupaten Sidoarjo.

Nilai Risk Ratio pada variabel kepemilikan SIM C dengan kecelakaan lalu lintas adalah 1,533 yang artinya siswa yang tidak memiliki SIM C berisiko 1,533 kali lebih besar mengalami kecelakaan daripada siswa yang telah memiliki SIM C. Nilai 95\% Confidence Interval dari Risk Ratio $(0,797-$ $2,950)$ menunjukkan bahwa risiko tersebut tidak bermakna. Sementara nilai Risk Ratio pada variabel kepemilikan SIM C dengan pengetahuan berkendara adalah 1,008 yang artinya siswa yang memiliki SIM C berisiko memiliki pengetahuan yang baik 1,008 kali lebih besar daripada yang tidak memiliki SIM C. Nilai 95\% Confidence Interval pada Risk Ratio $(0,970-1,047)$ menunjukkan bahwa risiko tersebut tidak bermakna.

Tabulasi silang antara keikutsertaan dalam tes pembuatan SIM dengan kejadian kecelakaan lalu lintas menunjukkan bahwa dari 69 siswa yang telah memiliki SIM C, sebagian besar mengikuti tes pembuatan SIM sedangkan persentase kecelakaan lebih besar pada yang mengikuti tes pembuatan SIM. Sementara tabulasi silang antara keikutsertaan dalam tes pembuatan SIM dengan pengetahuan berkendara menunjukkan persentase siswa yang mengikuti tes SIM lebih besar pada pengetahuan berkendara kategori baik namun peserta yang tidak mengikuti tes SIM semuanya berpengetahuan berkendara kategori baik. Uji fisher's exact tabel kontingensi 2 x 2 digunakan untuk melihat hubungan keikutsertaan dalam tes pembuatan SIM dengan kecelakaan lalu lintas menghasilkan $p$ value sebesar 1,00 dimana nilai ini lebih besar dibanding $0,05(\alpha)$ yang artinya tidak ada hubungan antara keikutsertaan dalam tes SIM dengan kecelakaan lalu lintas pada siswa SMA kelas XI di Kabupaten Sidoarjo. Sementara uji fisher's exact untuk melihat hubungan antara keikutsertaan dalam tes pembuatan SIM dengan pengetahuan berkendara menghasilkan $p$ value sebesar 1,00 dimana nilai tersebut lebih besar dari $0,05(\alpha)$ yang artinya tidak ada hubungan antara keikutsertaan dalam tes pembuatan SIM dengan pengetahuan berkendara.

Nilai Risk Ratio pada variabel keikutsertaan dalam tes pembuatan SIM dengan kejadian kecelakaan lalu lintas adalah 0,586 yang artinya para siswa yang tidak mengikuti tes pembuatan SIM dalam mendapatkan SIM C berisiko 0,586 kali mengalami kecelakaan lalu lintas daripada siswa yang mengikuti tes pembuatan SIM untuk mendapatkan SIM C. Nilai 95\% Confidence Interval dari Risk Ratio (0,0824,171) menunjukkan bahwa risiko tersebut tidak bermakna. Sementara nilai Risk Ratio pada variabel keikutsertaan dalam tes pembuatan SIM dengan pengetahuan berkendara adalah 0,983 yang artinya siswa yang mengikuti tes SIM untuk mendapatkan SIM C berisiko memiliki pengetahuan berkendara yang baik sebesar 0,983 kali daripada siswa yang tidak mengikuti tes SIM untuk mendapatkan SIM C. Nilai 95\% Confidence Interval pada Risk Ratio $(0,950$ 1,017) menunjukkan bahwa risiko tersebut tidak bermakna.

\section{PEMBAHASAN}

\section{Gambaran Karakteristik Responden}

Dari hasil penelitian ini dapat diketahui bahwa distribusi karakteristik responden menurut jenis kelamin memiliki persentase hampir sama besar antara pengendara lakilaki maupun perempuan namun masih lebih banyak responden perempuan. Pada jaman modern ini tidak hanya laki-laki saja yang banyak di jalan raya, para perempuan telah mempunyai pola hidup baru untuk hidup mandiri dalam berkendara, mereka memilih bekerja di luar rumah dan memilih kendaraan 
roda dua sebagai sarana transportasinya. Jumlah pelanggaran lalu lintas didominasi oleh laki-laki tiap tahunnya, namun seiring bertambahnya jumlah pengendara perempuan, pelanggaran lalu lintas juga kerap melibatkan pengendara perempuan. (Sarry dan Widodo, 2014)

Baik laki-laki dan perempuan dalam berkendara pernah melakukan pelanggaran lalu lintas di jalan raya yang tidak sedikit dapat menimbulkan kecelakaan lalu lintas. Laki-laki secara teknis lebih baik dalam menguasai kemudi dan jalan namun menurut teori Anderson dkk (Baron, 2012) laki-laki lebih agresif dan dominan serta cenderung berani mengambil risiko. Hal inilah yang dapat membahayakan ketika berkendara di jalan raya, sedangkan perempuan secara psikologis lebih mendahulukan emosi daripada logika, lebih mudah cemas dan marah. Hal inilah yang menjadikan perilaku berisiko berkendara perempuan juga tinggi sehingga pelanggaran yang dilakukan oleh perempuan juga tidak sedikit (Agung, 2014).

Distribusi karakteristik responden menurut riwayat kecelakaan menunjukkan hanya sebagian kecil responden yang pernah mengalami kecelakaan selama enam bulan terakhir terhitung ketika bulan penelitian di lakukan. Distribusi karakteristik responden berdasarkan kepemilikan SIM $\mathrm{C}$ menunjukkan tidak sampai setengah dari total responden memiliki SIM C padahal para siswa yang menjadi responden dalam penelitian ini telah berumur minimal 17 tahun dan merupakan pengendara aktif sepeda motor. Undang-Undang No 22 tahun 2009 tentang lalu lintas dan angkutan jalan pasal 77 menyebutkan bahwa setiap orang yang mengemudikan kendaraan bermotor di jalan raya wajib memiliki SIM sesuai jenis kendaraan bermotor yang dikemudikan. Pada pasal 80 dan 81 UU No. 22 tahun 2009 tentang lalu lintas dan angkutan jalan juga menyebutkan bahwa SIM C merupakan SIM yang diperuntukkan bagi pengendara sepeda motor dan usia minimal untuk mendapatkan
SIM C adalah 17 tahun. Sanksi yang diberikan bagi pengendara yang tidak memiliki SIM juga tidak sedikit. Undang-Undang No. 22 tahun 2009 tentang lalu lintas dan angkutan jalan pasal 281 menyebutkan bahwa sanksi bagi setiap pengendara kendaraan bermotor di jalan raya yang tidak memiliki SIM adalah pidana kurungan paling lama empat bulan atau denda paling banyak satu juta rupiah.

Distribusi karakteristik responden berdasarkan keikutsertaan dalam tes pembuatan SIM menunjukkan bahwa lebih dari setengah responden mengikuti tes pembuatan SIM. Menurut Undang-Undang No. 22 tahun 2009 tentang lalu lintas dan angkutan jalan pasal 81 menyebutkan bahwa untuk mendapatkan Surat Ijin Mengemudi (SIM) setiap orang harus memenuhi persyaratan antara lain persyaratan usia, administratif, kesehatan dan lulus ujian. Syarat lulus ujian yang dimaksud disini meliputi ujian tulis, ujian praktik, dan/atau ujian keterampilan melalui simulator.

Bagi pemohon SIM yang lolos semua ujian, pembuatan SIM dapat dilakukan dalam sehari namun bagi pemohon SIM yang mengulang ujian dibutuhkan waktu lebih panjang untuk mendapatkan SIM dan kebanyakan pemohon SIM tidak lolos ujian SIM dalam satu kali coba. Hal inilah yang dirasa memotivasi para pemohon SIM untuk menggunakan jasa calo SIM demi mendapatkan SIM meskipun harus mengeluarkan uang yang tidak sedikit karena kemudahan dan cepat tanpa harus melalui serangkaian prosedur pengurusan SIM terutama ujian praktik. Selain alasan yang telah disebutkan sebelumnya, para pemohon SIM lebih memilih menggunakan calo SIM karena dorongan emosional antara calon pemohon SIM dengan calo SIM, dan adanya kebiasaan yang turun temurun dari keluarga atau orang terdekatnya (Laksmita dan Wahyudi, 2017). Menurut Undang-Undang No. 22 tahun 2009 tentang lalu lintas dan angkutan jalan pasal 86 menyebutkan bahwa salah satu fungsi SIM merupakan sebagai bukti kompetensi mengemudi. Jadi untuk 
menjalankan fungsi tersebut dibutuhkan dan diwajibkan melewati serangkaian persyaratan pembuatan SIM yang salah satunya adalah lolos serangkaian ujian yang dapat dijadikan sebagai penilaian pengetahuan dan keterampilan berkendara para pemohon SIM.

Distribusi karakteristik responden berdasarkan pengetahuan berkendara menunjukkan bahwa hampir semua responden memiliki pengetahuan berkendara yang baik. Menurut teori Lawrence Green, pengetahuan merupakan salah satu faktor predisposisi atau faktor pendorong yang dapat menentukan perilaku manusia. Menurut penelitian Wesli (2015), pengetahuan berkendara berpengaruh terhadap perilaku berkendara pengendara sepeda motor.

\section{Hubungan Kepemilikan SIM C dengan Kecelakaan Lalu Lintas}

Hasil analisis penelitian menunjukkan bahwa kepemilikan SIM C tidak memiliki hubungan yang signifikan dengan kejadian kecelakaan lalu lintas. Hal ini sejalan dengan penelitian Fikriyah (2016) yang menyatakan kepemilikan SIM tidak berhubungan dengan persepsi keselamatan mengendarai sepeda motor. Persepsi keselamatan berkendara yang buruk dapat berisiko terjadinya kecelakaan lalu lintas. Sementara penelitian yang dilakukan oleh Zaman, dkk (2015) menyatakan sebaliknya bahwa kepemilikan SIM C berhubungan dengan perilaku keselamatan berkendara sepeda motor.

Pada penelitian yang dilakukan oleh Adisasmita, dkk (2013) menyatakan bahwa persentase terbesar untuk kejadian kecelakaan lalu lintas dari tahun 2010 hingga 2012 di Kabupaten Mamuju, Sulawesi Barat melibatkan para pengendara tanpa SIM.

Menurut penelitian yang dilakukan oleh Ouimet et al (2007) menyatakan bahwa para remaja yang telah memiliki SIM cenderung berperilaku safety riding yag baik pada awal kepemilikan SIMnya. Perilaku safety riding yang baik ini salah satunya karena persepsi keselamatan yang baik pula.

Salah satu upaya untuk mengurangi angka kecelakaan lalu lintas dan berbagai dampak akibat kecelakaan lalu lintas di jalan raya adalah perilaku safety riding. Penelitian yang dilakukan oleh Asdar, dkk (2013) menunjukkan bahwa responden yang telah memiliki SIM sebagian besar berperilaku safety riding baik di jalan dan proporsi untuk perilaku safety riding yang baik lebih tinggi pada yang telah memiliki SIM daripada yang tidak memiliki SIM serta terdapat hubungan antara kepemilikan SIM dengan perilaku safety riding sehingga dapat disimpulkan bahwa kepemilikan SIM berpengaruh pada sikap atau perilaku safety riding yang baik.

\section{Hubungan Keikutsertaan dalam Tes Pembuatan SIM dengan Kecelakaan Lalu Lintas}

Hasil analisis penelitian menunjukkan bahwa keikutsertaan dalam tes SIM C tidak memiliki hubungan yang signifikan dengan kejadian kecelakaan lalu lintas. Menurut pasal 86 Undang-Undang No. 22 tahun 2009, salah satu fungsi SIM adalah sebagai bukti kompetensi mengemudi bagi pemegangnya, jadi dengan memiliki SIM, seseorang dianggap telah berkompeten dalam mengendarai kendaraan karena telah melewati beberapa proses dalam pembuatan SIM dimana ada proses untuk menilai pengetahuan berkendara dan kemampuan dalam mengendarai kendaraan dengan ujian tulis dan praktik.

Selandia Baru memperkenalkan Graduated Driving License Scheme (GDLS) sebagai upaya mengurangi kecelakaan lalu lintas pada anak muda dengan cara membentuk para pengendara baru kendaraan bermotor dengan pengalaman berkendara dan keterampilan secara bertahap di lingkungan berisiko rendah. GDLS membuat aturan terpisah yang dilakukan secara bertahap untuk driver pemula melalui klasifikasi lisensi. Tahap pertama merupakan tahap 
lisensi pelajar dimana pengemudi pemula harus didampingi supervisor yang harus dan telah memegang SIM lengkap selama minimal dua tahun dan pengemudi pada tahap ini tidak diperkenankan mengemudi antara jam 10 malam dan jam 5 pagi, serta batas konsumsi alkohol legal yang diperbolehkan sangat rendah (efektif nol). Tahap kedua adalah tahapan lisensi terbatas dimana pengemudi diperbolehkan mengemudi tanpa pengawasan namun tetap dalam kondisi seperti tahapan lisensi pelajar dan tahap ketiga merupakan tahap lisensi penuh dimana pengemudi diijinkan mengemudi setiap saat dengan membawa penumpang. Sehingga untuk mendapatkan lisensi penuh, sesorang tidak hanya diwajibkan untuk melakukan tes tertulis untuk menilai pengetahuan berkendara, tetapi juga perlu melewati beberapa tahapan klasifikasi lisensi untuk mengasah keterampilan dan pengalaman mengemudi guna menurunkan angka kecelakaan lalu lintas.

\section{Hubungan Kepemilikan SIM C dengan Pengetahuan Berkendara}

Hasil analisis penelitian menunjukkan bahwa para responden masih banyak yang belum memiliki SIM C padahal usia mereka merupakan usia minimum untuk dapat memiliki SIM yakni 17 tahun. Hasil analisis juga menyatakan bahwa kepemilikan SIM $\mathrm{C}$ dengan pengetahuan berkendara tidak memiliki hubungan yang signifikan.

Pasal 77 ayat 3, Undang-Undang No. 22 tahun 2009 tentang lalu lintas dan angkutan jalan menyebutkan bahwa seorang pengemudi yang ingin mendapatkan SIM diharuskan telah memiliki kompetensi dalam mengemudi yang dapat diperoleh melalui belajar secara mandiri atau melalui pendidikan dan pelatihan. Kompetensi ini nantinya akan diuji ketika ujian untuk mendapatkan SIM, sehingga diharapkan dengan memiliki SIM, para pengendara sudah memiliki kompetensi yang baik dalam berkendara.
Undang-Undang No. 22 tahun 2009 tentang lalu lintas dan angkutan jalan pasal 81 menyebutkan bahwa salah satu fungsi Surat Ijin Mengemudi adalah sebagai bukti kompetensi mengemudi bagi pemiliknya. Jadi memiliki SIM dapat menjadi tolak ukur pengetahuan dan kemampuan berkendara pemilik SIM, sehingga diharapkan dengan memiliki SIM para pengguna kendaraan bermotor telah memiliki pengetahuan berkendara yang baik karena untuk memperoleh SIM, para pemohon SIM diwajibkan untuk lulus tiap tes yang diujikan.

Setiap pengendara kendaraan bermotor yang merupakan pengguna jalan memerlukan pengetahuan akan aspek keselamatan berkendara. Pengetahuan akan aspek keselamatan berkendara didapatkan seseorang baik melalui pengalaman pribadi maupun orang lain dan juga literatur. Pengendara dengan pengetahuan serta keterampilan dan pengalaman berkendara dengan aman yang kurang berisiko tinggi mengalami kecelakaan dan cedera (Hidayati, 2015).

\section{Hubungan Keikutsertaan dalam Tes Pembuatan SIM dengan Pengetahuan Berkendara}

Hasil analisis penelitian menunjukkan bahwa keikutsertaan dalam tes pembuatan SIM tidak memiliki hubungan yang signifikan dengan pengetahuan berkendara. Undang-Undang No. 22 tahun 2009 pasal 81 menyebutkan bahwa setiap orang harus melalui beberapa persyaratan untuk mendapatkan SIM antara lain persyaratan usia, administratif, kesehatan dan lulus ujian yang meliputi ujian tulis, ujian praktik dan/ atau ujian keterampilan melalui simulator. Dapat disimpulkan bahwa ujian yang wajib dilewati para pemohon SIM untuk mendapatkan SIM adalah ujian tulis dan praktik. Ujian ini dilakukan untuk menilai kompetensi mengemudi seseorang. Seseorang yang mengikuti ujian atau tes pembuatan 
SIM dan lulus ujian tulis maupun praktik dapat disimpulkan berpengetahuan baik dalam berkendara.

\section{SIMPULAN}

Kesimpulan dari penelitian ini adalah kedua variabel bebas yang diteliti yakni kepemilikan SIM C dan keikutsertaan dalam tes pembuatan SIM menunjukkan bahwa tidak ada hubungan yang bermakna dengan kejadian kecelakaan lalu lintas maupun pengetahuan berkendara pada siswa SMA kelas XI di Kabupaten Sidoarjo tahun 2017 namun meskipun tidak ada hubungan yang signifikan antara kepemilikan SIM dan keikutsertaan dalam pembuatan tes SIM dengan kecelakaan lalu lintas dan pengetahuan berkendara sebaiknya hal ini tetap menjadi hal yang patut diperhatikan karena pentingnya kepemilikan SIM dan keikutsertaan dalam tes pembuatan SIM dalam menilai pengetahuan dan keterampilan berkendara para pengemudi sehingga dapat meningkatkan perilaku safety riding yang baik sehingga dapat menurunkan angka kejadian kecelakaan lalu lintas.

Upaya untuk meminimalisir kejadian kecelakaan lalu lintas pada usia produktif khususnya siswa SMA dapat dilakukan dengan cara menindak tegas para siswa yang belum memiliki SIM dan mengendarai sepeda motor sendiri ke sekolah. Orang tua juga diharapkan melarang putra/ putrinya untuk mengendarai sepeda motor di lingkungan sekitar rumah ketika belum memiliki SIM dan memberikan alternatif lain dengan menggunakan jasa transportasi umum atau jasa antar jemput. Kepemilikan SIM dapat menjadi tolok ukur kompetensi mengemudi seseorang, sehingga pada saat pembuatan SIM diwajibkan untuk mengikuti prosedur dan persyaratan yang ada, termasuk ujian tulis dan praktik.

\section{DAFTAR PUSTAKA}

Agung, I.M. 2014. Model Perilaku Pengendara Berisiko pada Remaja.Jurnal Psikologi Integratif. (Online), Vol. 2, No. 2, (http:// download.portalgaruda.org/article.php? article $=397686 \& \mathrm{val}=8723 \&$ title $=$ Mode $1 \% 20$ Pengendara $\% 20$ Berisiko $\% 20 \mathrm{Pada}$ \%20Remaja), 06 Agustus 2017.

Asdar, M., Rismayanti, Sidik, D. 2013. Perilaku Safety Riding pada Siswa SMA di Kabupaten Pangkep, (Online), (http://repository.unhas.ac.id/ bitstream/handle/123456789/4246/ M U H A M M A D \% 20 A S D A R K11109367.pdf), 06 Agustus 2017.

Baron, R.A., Byne, D. 2012. Psikologi Sosial jilid 2. Jakarta: Erlangga.

BPS Provinsi Jawa Timur. 2015. Jawa Timur dalam Angka 2015. Surabaya: BPS Provinsi Jawa Timur. (http://www. jatim.bps.go.id/4dm!n/pdf_publikasi/ Jawa-Timur-Dalam-Angka-2015.pdf), 30 Juli 2017.

Departemen Perhubungan. 2009. UndangUndang No. 22 Tahun 2009 tentang Lalu Lintas dan Angkutan Jalan. Jakarta: ? (http://hubdat.dephub.go.id/uu/288uu-nomor-22-tahun-2009-tentang-lalulintas-dan-angkutan-jalan/download), 30 Juli 2017.

Fikriyah, N. 2016. Faktor-Faktor yang Berhubungan dengan Persepsi Keselamatan Mengendarai Sepeda Motor pada Siswa di Sekolah Menengah Atas (SMA) Kota Depok Tahun 2016. Skripsi. Jakarta: Universitas Islam Negeri Syarif Hidayatullah Jakarta.

Hidayati, A. 2015. Hubungan Jenis kelamin dan Faktor Perilaku Pengendara Sepeda Motor dengan Kecelakaan Lalu Lintas di Kecamatan Wonokromo Surabaya pada Siswa SMP Tahun 2015. Skripsi. Surabaya: Universitas Airlangga. 
Kingham, S., et al . 2008. The Impact of the Graduated Driver License Scheme on Road Traffic Accident Youth Mortality in New Zealand. Journal of Transport Geography. (Online), Vol. 16, (http;// dannydorling.org/wp-content/files/ dannydorling_publication_id0421.pdf), 06 Agustus 2017.

Kordelia, C.D., Yossyafra, Kurniati, T. 2014. Model Kecelakaan Lalu Lintas berdasarkan Korelasi Populasi, Tingkat Pemahaman Pengguna dan Tingkat Pertumbuhan Kendaraan di Kota Besar, Sedang dan Kecil Sumatera Barat. Jurnal Rekayasa Sipil. (Online). Vol. 10, No. 1, (http://jrs.ft.unand.ac.id/index.php/jrs/ article/download/v10-n1-kordelia/15), 23 Agustus 2017.

Kurniasari, N.D. 2013. Perbedaan Sikap Disiplin Berlalu Lintas Ditinjau dari Jenis Kelamin, (Online), (eprints. ums.ac.id/27622/19/02.NASKAH PUBLIKASI.pdf), 05 Agustus 2017.

Laksmita, A.H.M., Wahyudi, A. 2017. Rasionalitas Pengguna Jasa Calo dalam Pengurusan SIM Baru di Polres Sidoarjo. Paradigma. (Online), Vol. 5. No. 1, (jurnalmahasiswa.unesa.ac.id/ article/21244/39/article.pdf), 06 Agustus 2017.

Octama, C.I. 2014. Kecelakaan Lalu Lintas, Penyebab Kematian Tertinggi Ketiga di Indonesia. (http://www.beritasatu.com/ nasional/206885-kecelakaan-lalu-lintaspenyebab-kematian-tertinggi-ketiga-diIndonesia.html), 03 Agustus 2017.

Ouimet, M.C., et al .. 2007. Perceived Risk and Other Predictors and Correlates of Teenagers Safety Belt Use During the First Licensure. Traffic Injury
Prevention. (Online), Vol. 9, No. 1, (http://www.ncbi.nlm.nih.gov/pmc/ articles/PMC2739301/\#!po=0.480769), 08 Agustus 2017.

Saputra, R. 2016. Ini Jumlah Sepeda Motor di Indonesia. (http://m.viva.co.id/ motor/770916-ini-jumlah-sepeda-motordi-Indonesia), 03 Agusus 2017.

Sarry, Y.P., Widodo, H. 2014. Upaya Polisi Lalu Lintas dalam Meningkatkan Kedisiplinan Berlalu Lintas Pengendara Bermotor (Studi Deskriptif terhadap Program Kanalisasi Lajur Kiri pada Satlantas Polrestabes Surabaya). Kajian Moral dan Kewarganegaraan. (Online), Vol.2, No. 2, (http://jurnalmahasiswa. unesa.ac.id/article/10597/41/article.pdf) 06 Agustus 2017.

Wesli. 2015.Pengaruh Pengetahuan Berkendara terhadap Perilaku Pengendara Sepeda Motor Menggunakan Structural Equation Model (SEM). Teras Jurnal. (Online), Vol. 5, No. 1 (http://repository.unimal.ac.id/id/ eprint/119), 08 Agustus 2017.

WHO. 2015. Global Status Report on Road Safety 2015. Geneva: Management of Noncommunicable Diseases, Disability, Violence, and Injury Prevention (NVI). Tersedia di (http://www.who.int/ violence_injury_prevention/road_safety_ status/2015/GSRRS2015_Summary_ EN_final2.pdf?ua=1), 25 Juli 2016.

Zaman, H., Maria, I.L., Ansar, J. 2015. Determinan Perilaku Keselamatan Berkendara Sepeda Motor pada Remaja di Wilayah Pesisir Kabupaten Pangkep. (Online). (http://repository.unhas.ac.id/ handle/123456789/14427), 06 Agustus 2017. 